\title{
On the Roles of World-Class Universities and the Sustainability Agenda in Africa: A Case Study of Two Universities in South Africa and Egypt
}

\author{
Gladys Mutinda ${ }^{1} \&$ Zhimin Liu ${ }^{1}$ \\ ${ }^{1}$ Public Administration, Nanjing Agricultural University, Nanjing, China \\ Correspondence: Gladys Mutinda, Public Administration, Nanjing Agricultural University, Nanjing, China. \\ E-mail: gladysndungemutinda@outlook.com; Zhimin Liu, Public Administration, Nanjing Agricultural \\ University, Nanjing, China. E-mail: liuzhimin@njau.edu.cn
}

Received: August 26, 2021

Accepted: September 24, $2021 \quad$ Online Published: October 6, 2021

doi:10.5539/hes.v11n4p70

URL: https://doi.org/10.5539/hes.v11n4p70

\begin{abstract}
In the past decade, the World Class University discussion has become rampant due to the integral role that higher education plays in any economy's aspiration to compete globally while still pursuing sustainability. This article reports on a study that explored the roles played by world-class universities (WCUs) in fostering sustainability initiatives and practices in the African context. The article harnesses a document review approach that facilitates in-depth document analysis using two world-class institutions in Africa: The University of Cape Town in South Africa and American University in Cairo in Egypt as case studies. This study finds that world-class institutions in the two countries have rigorous, comprehensive sustainability organisations, synthesised and adopted from international agreements and concepts. The sustainability organisation is characterised by a less hierarchical approach to its management and leadership. Sustainability in research is fostered through environmental research and other key research areas such as food and medicine. Sustainable teaching is fostered through living-learning labs, redesigned curriculums, targeted degree programs and lecturer development through training and awards as incentives. Tangible, sustainable technology and innovation initiatives are also evident. This article comprehensively establishes the links and roles played by WCUs in fostering sustainability. It aids potential WCUs in Africa to understand and adopt sustainable initiatives within different and dynamic institutional contexts.
\end{abstract}

Keywords: Africa, higher education, sustainability initiatives, world-class universities

\section{Introduction}

The world-class institution today plays an essential and central role in promoting and fostering sustainable higher education. The WCU discussion is, therefore, one that has ostensibly become rampant in the past decade owing to the integral role that higher education plays in any economy's aspiration to compete globally while still pursuing sustainability (Leal et al., 2018; Martinez et al., 2021). The tenets of sustainability in higher education are emerging from the oversight of vagueness and imprecision. As such, World-Class Universities (WCU) are the emerging avenues for promoting the principles of sustainability. Current research and practice have focused on integrating sustainable development initiatives into the core system elements of higher education such as research, management, education, partnership and collaborations, thus making sustainability a crucial aspect of the institutional framework (Lozano et al., 2015; Lozano et al., 2017; Lozano et al., 2013; Saqib et al., 2020).

Higher education institutions (HEIs) are recognised as stable drivers for sustainability development and can overcome challenges of achieving sustainable development by designing processes that bring change for students and faculty (Stephens et al., 2008; Aleixo et al., 2018; Vargas et al., 2019). HEIs are involved in the achievement of sustainable development since the 1972 Stockholm Declaration. Since then, a myriad of other global initiatives have sprouted up, such as the United Nations Higher Education Sustainability Initiative (UN HESI) and the United Nations Higher Education and Research for Sustainable Development (HESD) (UN, 1992). These sustainability initiatives, simply put, call on the leaders of the international academic community to commit to the development of sustainable practices while rethinking ways of learning, teaching, research, innovation and technology in order to rebuild strong and sustainable higher education institutions and societies 
(Zou et al., 2015). As such, sustainability actions must be integrated and prioritised in a higher education institutional setting as goals and plans intended to address the societal need for a transition to a resilient society (Steffen et al., 2015).

Universities are vital institutions that act as sustainability models in their own physical space by enhancing a globally sustainable future through research and teaching (Wu and Shen, 2016). Research proves that education (and, in this case, higher education) plays pivotal roles in promoting and raising awareness of sustainability (Fiksel et al., 2013). Essential elements characteristic of sustainable universities include the curriculum, research, management, outreach and service, and institutional missions and planning (Calder et al., 2003). Therefore, it is fundamentally paramount that higher education embraces sustainability as both the political and economic sectors have already taken significant steps. This way, higher education inculcates sustainability agendas that can be useful in creating societies and a workforce that is sensitive towards sustainability (Martin and Jucker, 2005).

This article, therefore, presents evidence on critical concepts and the existent links between the world-class university discussion and sustainability. A plethora of studies indicate efforts by multitudes of institutions in implementing sustainability. However, as sustainability is currently a novel concept in higher education, research linking and delving deeply into understanding the existing relationship between world-class institutions and sustainability is far lacking. Comprehensively, this study situates the WCU discussion as crucial towards its reflection on the roles the WCU plays towards fostering and implementing sustainability initiatives and practices in the African region.

\subsection{The Context}

Elite world-class institutions such as Harvard and Yale show distinct characteristics in implementing sustainability initiatives in their institutions. Elite institutions have had sustainability agendas and initiatives since time immemorial. They are old institutions characterised by high standards, with students at the top echelon and renowned professors. These institutions have solid sustainability organisations characterised by all-comprehensive plans outlined with tangible, sustainable goals and initiatives. The institutions run on full institutional and academic autonomy that allows them to fully carry out their academic mandate without unnecessary interference and bureaucracies and foster strong governance structures to integrate sustainability-embedded practices in all the initiatives on all levels at the university (Yale, 2019). These institutions also practice a top-down approach to sustainability which entails institutional declarations at the university management levels on how sustainability organisation, strategies and practices are to be carried out (Beringer and Adomßent, 2008). Harvard, for instance, has set clear university-wide goals on the sustainability of the environment and incorporated these plans into research, innovation and learning (Harvard, 2019).

Elite institutions also pay more attention to sustainable research that focuses mainly on global issues such as Harvard's efforts towards climate change on a global stage and environmental degradation through solid research at the institution (Harvard, 2019). Research at these elite institutions is also long-term oriented, addressing and targeting future challenges while seeking long-lasting solutions. In addition, these institutions focus on promoting sustainability in teaching through instilling and shaping global leaders who will lead the sustainable agenda on the right track. Harvard is committed to nurturing new generations of leaders who are conscious about sustainability agendas. Sustainability in teaching at elite institutions is also fostered through the creation of new sustainability-related curricula. Teaching is mainly focused on spurring creativity and innovation as opposed to mere mechanistic knowledge transmission. As Elite institutions engage in diverse, sustainable cutting -edge innovative activities and have in place extensive resources in funding and infrastructure, their technology and innovation levels are also on a large scale.

Africa has by far the least number of recognised world-class institutions with less than $5 \%$ of its institutions represented in the league tables compared to the rest of the world, as indicated in Table 1, which indicates the regional distribution of WCUs for the year 2019/2020 regionally. This scenario is because establishing a WCU is such a tedium task (Lee, 2013) illuminates this dilemma where he questions the ability of every country that aspires to establish a WCU. 
Table 1. Regional distribution of WCUs for the year 2019/2020 from ARWU, QS and THE

\begin{tabular}{lllllll}
\hline & ARWU & & QS & & \multicolumn{2}{l}{ WORLD UNIVERSITY RANKING(THE) } \\
\hline Region & No. of Univ & $\%$ & No. of Univ & $\%$ & No. of Univ & $\%$ \\
\hline Americas & 165 & 33 & 270 & 29 & 225 & 23 \\
Europe & 204 & 41 & 348 & 38 & 415 & 42 \\
Asia/Oceania & 126 & 25 & 281 & 31 & 315 & 32 \\
Africas & $\mathbf{5}$ & $\mathbf{1}$ & $\mathbf{1 7}$ & $\mathbf{2}$ & $\mathbf{2 5}$ & $\mathbf{3}$ \\
Total & 500 & 100 & 916 & 100 & 980 & 100 \\
\hline
\end{tabular}

Data sources: Ranking data are from each ranking in 2019/2020. The ranking data is available from: ARWU (http://www.shanghairanking.com/)

THE (https://www.timeshighereducation.com/world-university-rankings/)

(Qs) (http://www.topuniversities.com/university-rankings/)

The presence of few WCUs in Africa can also be attributed to the African political and economic issues that have contributed to the slower pace of establishing world-class universities. In Lee (2013) only a few developing countries can foster a WCU and that it is quite strenuous for many universities in developing countries to achieve world-class status. What plagues the WCU in Africa is tons of challenges ranging from budgets crisis, quality issues, poor governance and stringent bureaucracies to security and lack of sufficient resources and infrastructure (Lee, 2013). However, this study argues that despite few WCUs in Africa, they play critical roles in fostering sustainability initiatives and practices necessary for sustainable African higher education institutions.

African WCUs, unlike their elite counterparts, are only at the incipience of embracing sustainability initiatives in the recent decade. This may be so, as African institutions are grappled with many challenges daily in terms of low quality, stringent resources, funding, and infrastructure to facilitate sustainability practices fully. Conversely, governance and organisation sustainability in African WCUs is characterised by tons of bureaucratic hierarchies that hinder progress. These institutions, however, notably practise a bottom-up approach to their sustainability practices which involves individual sustainability campaigns and projects that foster institutional transformation at the department and individual levels (Beringer and Adomßent, 2008). Even so, their sustainability plans are at times loosely detached and somewhat abstract. At the same time, research in African WCUs is more targeted on national challenges and is often short-term oriented. Moreover, sustainability in teaching at African WCUs leans more towards knowledge transmission orientation and thus proves lacking in creativity. Notwithstanding, African WCUs focus on low scale technology and innovation practices as they have limited resources in their reach in terms of funding and infrastructure.

The comparison presented of both elite and African WCUs does not seek to do so only through a spectrum of competitiveness but rather through illuminating and exemplifying best practices in sustainability as carried out by elite institutions. This provides a transformative value and a learning approach for African WCUs to understand and fully embrace concepts of fostering and implementing sustainability initiatives and practices.

The current research gap exists in establishing while providing concrete evidence of the roles played by WCUs towards fostering sustainability. Within this broad framework, this study focuses its lens on exploring while offering an augmented and integrated view through a comparative analysis on the roles of WCUs in fostering sustainability within two distinct case studies of WCUs in Africa based in different cultures socially, politically and economically. The study has identified the University of Cape Town (UCT) and the American University in Cairo (AUC)) as case studies, assessing the conceptualisation and implementation of sustainability initiatives, strategies and practices. The study constructs this argument and proposes a conceptual framework for modelling and understanding the influence of WCUs on sustainability and isolates four paradigms that aid in exploring the solid bases in which WCUs would foster sustainability. Our conceptual analysis confirms and situates the roles of WCUs while further illustrating how these paradigms interact inextricably to ensure effective and sustainable higher education. This study is essentially paramount as it will go a long way in advancing and increasing the knowledge base and grounding on understanding the roles played by WCUs in fostering the sustainability agenda. The study will illuminate the concepts, implementation and general trends as the WCUs in Africa develop sustainability initiatives and strategies. While there is an extensive conduit of knowledge and research devoted to WCUs and sustainability discussions independently, it is exhaustive but not entirely new. Negligible attention (to the best of our knowledge) has been paid to research that delves deep into establishing the existent links and roles played by WCUs and their pedagogical approaches towards fostering sustainability initiatives, 
strategies and practices (Lozano et al., 2019).

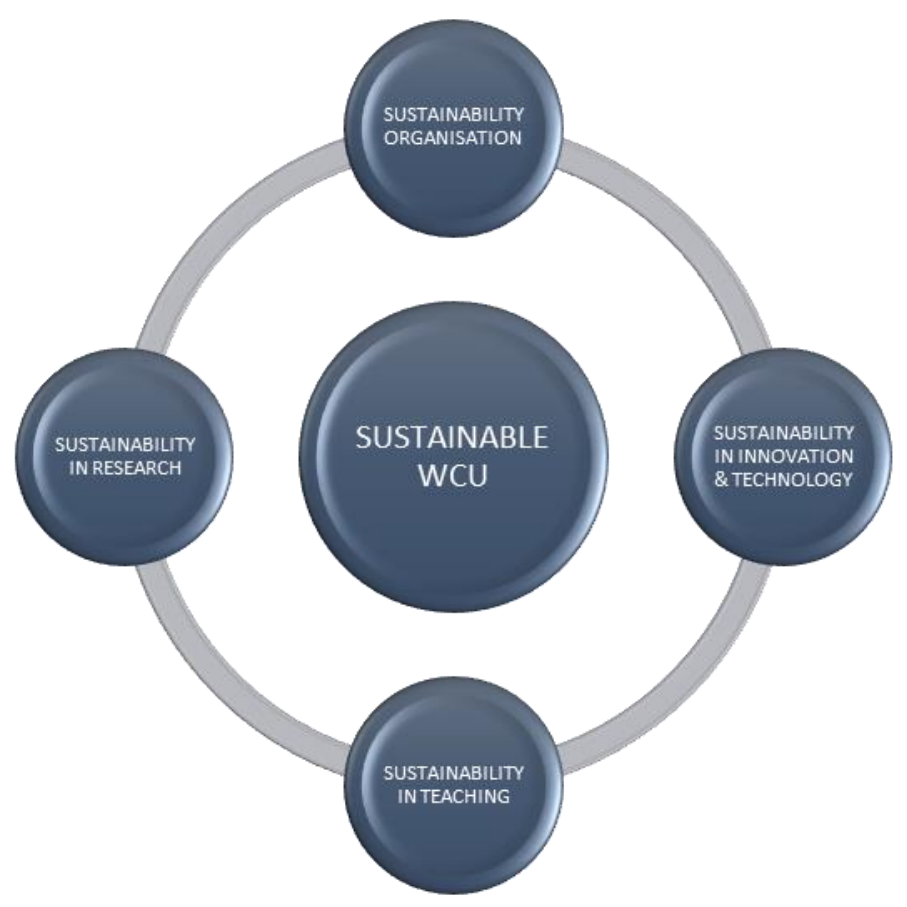

Figure 1. A framework for understanding the roles of WCUs in fostering sustainability initiatives

Source: Author's compilation

The concise conceptual framework presented in Figure 1 models and offers an augmented and integrated view on the roles of WCUs in advancing sustainability initiatives for the African region through establishing an existent link between sustainability and WCUs. The proposed conceptual framework comprises three paradigms (sustainability research, teaching, innovation and technology) that world-class institutions engage in to actively foster sustainability. The framework provides a better understanding of the roles of WCUs in fostering sustainability. This is required given that these three paradigms interact systematically to ensure a sustainable WCU.

\section{Methodology}

This study uses a document review approach that facilitates in-depth bibliographical literature review, desk research on various web searches, reports, publications and provides a critical review of the sustainability practices and initiatives in recognised WCUs in Africa. In addition, we employ the case study method where the study identified top-ranked WCUs in two African countries: The University of Cape Town in South Africa and the American University in Cairo in Egypt. The case study method will not only enhance comprehension but will also reveal specific contexts and provides in-depth understanding while holistically providing transformative values in sustainability for other potential WCUs in Africa. These two institutions were selected as authentic case studies as they are ranked highly in three widely recognised global rankings: Times Higher Education (THE), Quacquarelli Symonds (QS) and ARWU all of the period 2019/2020. From this perspective, choosing the two institutions allows for effective comparisons between the institutions. The comparative study will illuminate general trends and contextual differences in understanding the roles played by WCUs in fostering and implementing sustainability initiatives. The study, however, acknowledges that these rankings use different methodologies and have been criticised over time over the same. These rankings, overall, are essentially useful as they encompass indicators that are commonly used as measures and evaluating nodes of the excellence of world-class universities.

\subsection{Comparison of Sustainability Initiatives and Implementation at the African WCUs}

The summary presented in Table 2 shows the strategic sustainability initiatives and practices that the two world-class institutions in Africa engage in light of various international declarations, agreements and initiatives 
coupled with best practices in sustainability.

Table 2. Summary of sustainability strategies and practices engaged in by the WCUs in Africa

\begin{tabular}{|c|c|c|}
\hline Sustainability actions engaged in & Thematic Paradigm & Implemented from \\
\hline $\begin{array}{l}\text { Incorporation of solid, content-specific sustainability } \\
\text { plans, integration of concepts and principles of } \\
\text { sustainability in the WCU } \\
\text { Indulge in sustainability initiatives that engage the } \\
\text { community through social responsiveness by } \\
\text { promoting holistic practices }\end{array}$ & $\begin{array}{l}\text { Sustainability } \\
\text { Organisation }\end{array}$ & $\begin{array}{l}\text { UN (2012) } \\
\text { (Lozano et al., 2015) } \\
\text { Bruntdland Report (1987) } \\
\text { Halifax Declaration (1991) } \\
\text { ISO (2014) }\end{array}$ \\
\hline $\begin{array}{l}\text { Performing multidisciplinary research on various } \\
\text { thematic angles (environment, climate, food security, } \\
\text { medicine) } \\
\text { Integration of collaboration and partnerships with } \\
\text { other institutions to create flourishing networks to } \\
\text { facilitate propitious backdrops for efficient and } \\
\text { effective research processes }\end{array}$ & $\begin{array}{l}\text { Sustainability } \\
\text { in Research }\end{array}$ & $\begin{array}{l}\text { Kyoto Declaration (1993) } \\
\text { Copernicus Charter (1994) } \\
\text { (Waas et al., 2010) } \\
\text { Swansea Declaration (1993) } \\
\text { Abuja Declaration (2009) } \\
\text { (Lauder et al., 2015) }\end{array}$ \\
\hline $\begin{array}{l}\text { Inclusion of themes related to sustainability in teaching } \\
\text { and learning through embedding sustainability in } \\
\text { curriculum and research } \\
\text { Invention of student-driven sustainability initiatives } \\
\text { Continuous curriculum assessment to promote the } \\
\text { development of extensive knowledge bases that } \\
\text { comply with sustainability practices }\end{array}$ & $\begin{array}{l}\text { Sustainability } \\
\text { in Teaching }\end{array}$ & $\begin{array}{l}\text { Turin Declaration (2009) } \\
\text { AASHE (2016) } \\
\text { AASHE (2019) } \\
\text { Bonn Declaration (2009) } \\
\text { (Gómez et al., 2015) } \\
\text { Lunenburg Declaration (2001) } \\
\text { Ubuntu Declaration (2002) }\end{array}$ \\
\hline $\begin{array}{l}\text { Establishing supportive systems to encourage the } \\
\text { growth of innovative ideas and inputs to address } \\
\text { challenges that face the WCU with regard to } \\
\text { sustainability } \\
\text { Promoting creativity, invention and innovative } \\
\text { research activities aimed at fostering sustainability }\end{array}$ & $\begin{array}{l}\text { Sustainability } \\
\text { in Technology } \\
\text { and Innovation }\end{array}$ & $\begin{array}{l}\text { Lozano et al. (2013) } \\
\text { ISO (2014) } \\
\text { Talloires Declaration (1990) } \\
\text { Agenda 21((UN), 1992) } \\
\text { Graz Declaration (2005) } \\
\text { Lozano (2014) }\end{array}$ \\
\hline
\end{tabular}

Source: Adapted and modified from Casarejos (2017)

\subsection{Sustainability Organisation}

The sustainability organisation at UCT is excellent and content-specific. This is evidenced by the presence of tangible sustainability plans adopted from the national constitution that provide mainly for environmental sustainability by providing equal rights to healthy and secure environments of the greater South Africa. As a world-class institution exuding excellence in Africa, UCT has been committed to sustainability since 1990 as part of the initial signatories of the Talloires Declaration and saw its recommitment in 2001. UCTs strides towards embracing sustainability is further reflected in the university mission declaration that echoes its allegiance in the contexts of teaching and research in the institution (UCT, 2019b). In 2012, this institution became a signatory to the ISCN-GULF sustainable Campus Charter, a worldwide forum committed to best practices in sustainability. Figure 2 shows that sustainability at UCT is organised and guided by the Environmental Management Working Group (EMWG) that was formed in 2001 whose mandate is to guide to properties and services on campus with regard to saving energy and the Green campus policy framework of 2008 that was adopted by the council and senate. This framework provides for responsible resource usage and the overall sustainability of the environment. These two sustainability initiatives bore the green campus action plan that oversees several student-oriented initiatives such as the student's representative council, Engineers without borders and the green campus initiatives. The UCT is characterised by a less hierarchical approach to sustainability(bottom-up) which involves individual declarations, strategies, campaigns at various departmental levels to instigate institutional transformation (Beringer and Adomßent, 2008).

The organisational structure of sustainability at AUC consists of a physical office of sustainability, the Centre for Applied Research on the Environment and Sustainability (CARES) and a neighbourhood initiative. The office of sustainability, established in 2011, reports to the office of associate vice president for campus services, as shown in figure 3. The office is mandated to address AUCs environmental challenges from climate change to waste management. The office is also responsible for cultivating sustainable research and addresses AUCs 
environmental issues such as resource scarcity, pollution and climate change. It also ensures the consolidation of environmental and social sustainability into the institutions' culture while cultivating a sustainability mindset for the higher education environment. The office is also tasked with raising awareness of environmental concerns that affect the AUC and the community at large. CARES which was formed due to the merger between the Centre for Sustainable Development (CSD) and the Research Institute for Sustainable Environment, is also a division that strategises and implements environmental sustainability.

Similarly, the AUC has tangible sustainability plans that range from the university's aim of decreasing carbon print to embedding sustainability in research and teaching. Sustainability focuses on both the campus and beyond through provision and guidance in raising public awareness through the neighbourhood initiative. This world-class institution focuses mainly on environmental sustainability while promoting social equity. AUCs sustainability goal is to integrate environmental initiatives and promote social sustainability while reducing the use of natural resources. The AUC is also characterised by a less hierarchical approach to sustainability where individual sustainability initiatives are carried out more by students and staff.

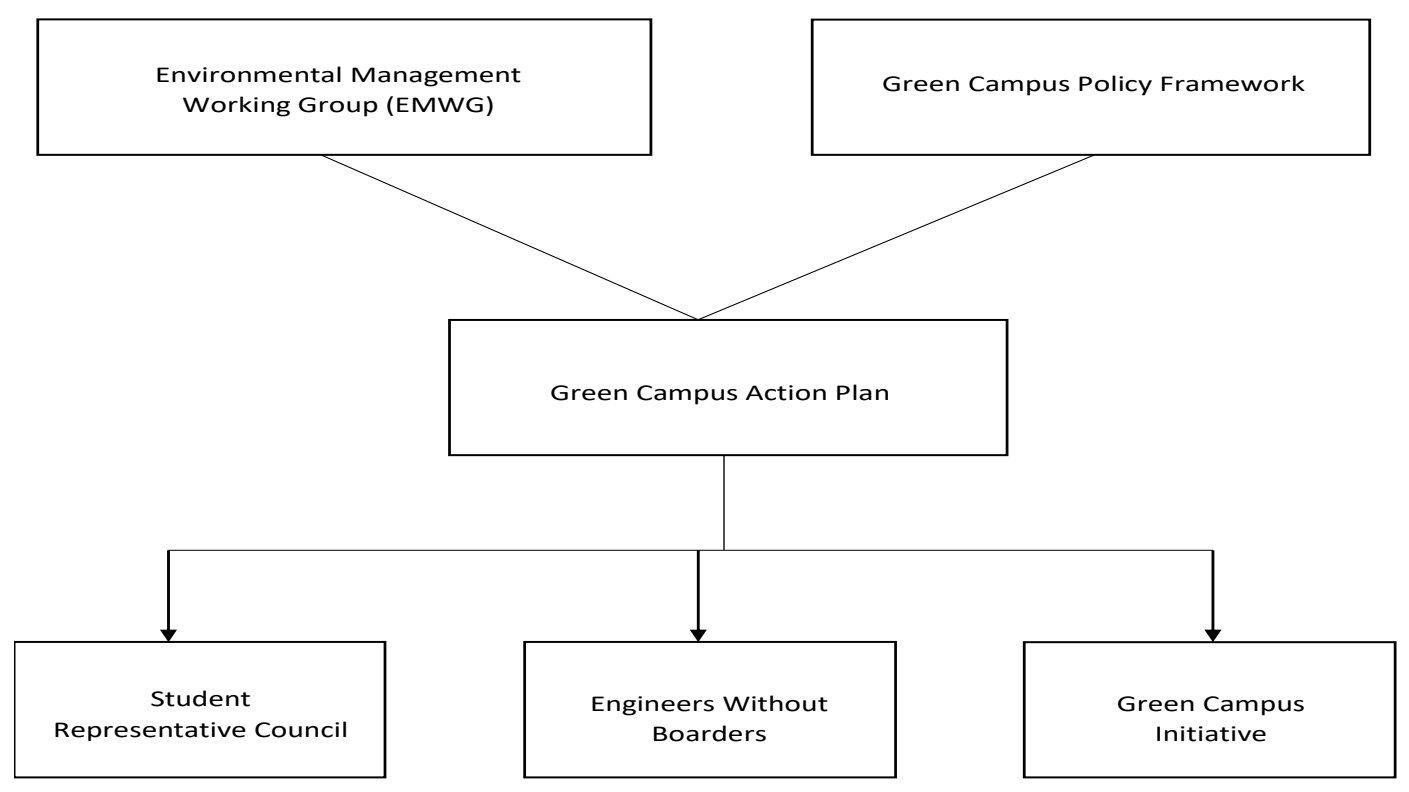

Figure 2. Sustainability organisation at University of Cape Town

Source: Author's compilation

Although these world-class institutions share some organisational similitude, this study finds that both the UCT and AUC have rigorous and comprehensive organisations with a tangible and detailed sustainability approach. Similarly, both institutions adopt their sustainability commitments from international organisations and agreements such as the Talloires and the United Nations sustainability agreements and declarations. Both institutions notably focus mainly on pursuing and promoting campus sustainability, where the focus is mainly at the university level. While this may be true, the AUC is concerned with pressing for sustainability beyond the campus through stretching its initiatives to promote social equity at the community level (social responsiveness). Notably, both institutions pay attention to environmental sustainability concerns, ranging from environmental protection to environmental awareness. In conjunction with this, the study finds that both institutions have a less hierarchical approach to the management and organisation of sustainability initiatives. Most of these initiatives are organised and led by students and staff at the department levels (bottom-up approach). The organisational differences displayed by the two world-class institutions in Africa reflects the varied understandings, workings and strategies regarding sustainability and, in turn, influences their sustainability approaches to research, teaching, technology and innovation paradigms. 


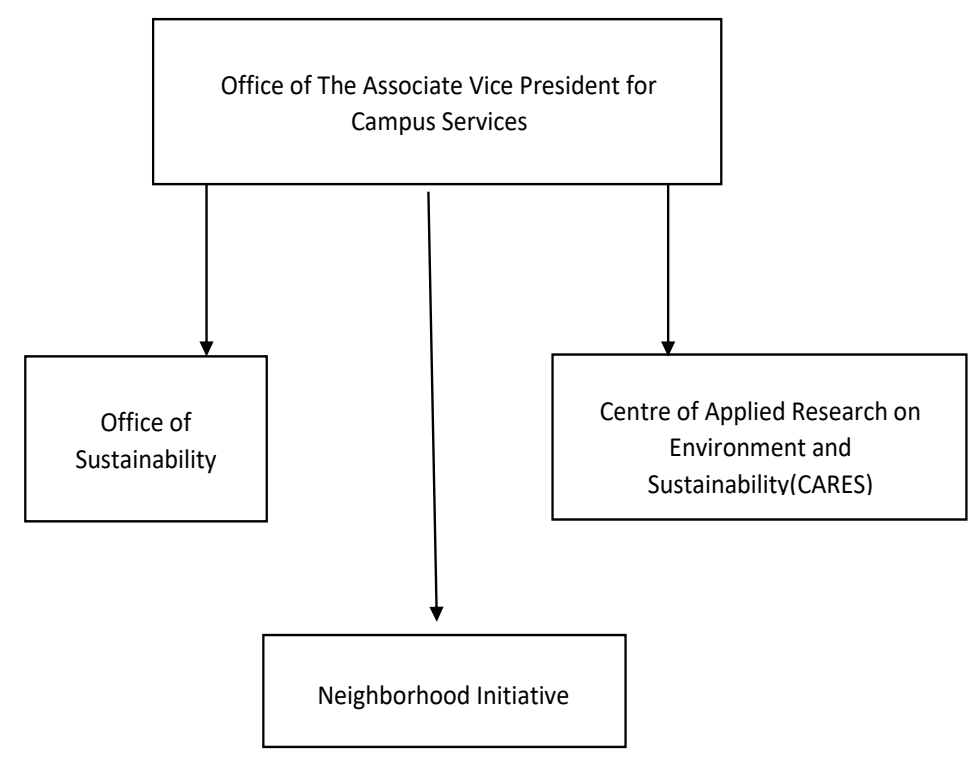

Figure 3. Sustainability organisation at the American University in Cairo

Source: Author's compilation

\subsection{Sustainability in Research}

Sustainability in research refers to the carrying out and production of research that facilitates essential and practical solutions to current and future challenges that plague higher education institutions in Africa and the world. As the creation of modern and up to date research has become a global endeavour, Africa's voice and footprints have been more undersized and often missing. Therefore, to ensure a sustainable future, world-class institutions in Africa must take a solid standing to ensure sustainable research of the highest quality that addresses future challenges.

Sustainable research in UCT is guided by the ISCN first principle that provides for the respect of nature and society where sustainability initiatives are integral to planning, construction renovation and management of all the buildings at the university (UCT, 2019b). Sustainable initiatives on the buildings include renewable energy technologies and electrical energy-efficient methods that facilitated the introduction of digital web-based metering, and in 2014 the metering extended to all the buildings at the institution. As South Africa is experiencing severe water crisis challenges, several research initiatives have been put in place at UCT, such as the water task team, raising awareness on water-related challenges. Sustainable conservation measures include promoting behaviour change towards water usage and installation of water-efficient fittings. UCT has in place sustainable waste and recycling measures that have been student-led since 2008. Such initiatives include tangible research on the separation of waste into recyclables and non-recyclables and the generation of small quantities of hazardous waste materials during the research (UCT, 2019b). UCT has put forward concrete initiatives towards ensuring sustainable research that is inquisitive driven and has a tangible impact on the future through its commitment to innovative research and scholarship to grapple with substantial issues that relate to both natural and social worlds. Revolutionary research, such as one that addresses the risks of tuberculosis immune reconstruction (TB-IRIS) that is quite common among HIV-positive people (UCT, 2018b). This is the kind of sustainable research that addresses challenges of the future world while providing dependable solutions to deal with these issues. An innovative research publication titled "Tomatoes and Taxi ranks: Running our cities to fill the food gap" is evidence of UCTs endeavours towards sustainable research that promotes food security while dwindling the food gap monumentally. To strengthen sustainable research nodes at the institution, international partnerships and collaborations vital for the production of active sustainable research in all WCUs and UCT have illustrated this by establishing extensive and flourishing networks of collaborations. Extensive research collaborations exist in UCT such as the African Research Universities Alliance (ARUA), International Alliance of Research Universities (IARU), and the Worldwide Universities Network (WUN) ensure the tackling of challenges that grapple African institutions through effective research that provides for the creation of centres of excellence and ensuring quality research excellence that is sustainable for the future (ARUA, 2018, IARU, 2018, 
WUN, 2018).

The AUC, as a notable WCU, has in place tangible, sustainable research initiatives that evidence its participation towards ensuring sustainability. The AUC has sixteen research centres that ensure collaborative and sustainable research initiatives across multiple disciplines. Such sustainable research initiatives range from climate change, carpooling support, water, waste and energy management, decreasing the institutions' carbon footprint to environmental research and ensuring public awareness. AUCs affirms its commitment towards ensuring a stable and sustainable higher education by the presence of a Research Institute for a Sustainable Environment (RISE) that carries out sustainable research through conducting research that promotes sustainable environments throughout Egypt. The research institute provides ample opportunities for students to learn and carry out research initiatives on environmental sustainability issues. The institute focuses its research on promoting sustainable management of critical resources for Egypt. There exist also some sustainable research projects towards social responsiveness in AUC. Research such as the rural agricultural mobile support system on mobile phone technology assists farmers with ensuring best practices for wheat farmers and climate-controlled greenhouses, all of which are crucial at addressing challenges of the now and the future. AUC has successfully seen the completion of varied sustainable research that will positively impact the future, such as the sustainable public transportation system within the institution and the AUC carbon footprints of both 2012,2013 and 2015 (AUC, 2018e). To support sustainable research, in place also is an active grants system that supports and motivates researchers towards innovative and sustainable research initiatives. These grants are competitively awarded to ensure support for individual or group research projects. The AUC has an active University Research Board (URB) that advocates for high standards with regard to ensuring sustainable research ethics, integrity and conduct. The URB advocates for quality sustainable research that cuts across all disciplines while addressing challenges faced in Egypt and the global world. The board promotes innovative and applied research while producing scholarly and creative works (AUC, 2018d, AUC, 2018g).

This study finds that both world-class institutions are engaged actively in sustainability initiatives in research, emphasising environmental sustainability research. For UCT, sustainability in research is concentrated on the environment and includes issues of social justice, food, and medicine. Accordingly, this study finds that both institutions emphasise research production with active research centres and research institutes. Similarly, both institutions have extensive propitious sustainable research collaborations and partnerships both regionally and internationally to strengthen and boost sustainable research.

\subsection{Sustainability in Teaching}

Sustainability in teaching refers to nurturing sustainable learning, which is not centred merely on a transmissive approach but rather on a transformative one. This kind of teaching does not rely on a dominant, mechanistic and reductionist paradigm but preferably seeks to develop transversal and autonomous capabilities in learners. Research currently focuses on incorporating a holistic approach to sustainability in teaching by integrating economic, social and environmental sustainability (Sinakou et al.2018). Research has also evolved from simply providing sustainability training and instruction to now include learning, capacity building and participation information on sustainability (Mintz and Tal, 2018). As suggested by Griffith and Moore (2020), it is paramount that universities integrate sustainability and and the SDGs into course delivery to protect future development and to avoid compromising future generations.

Sustainability in teaching is outlined in the ISCN principle three that seeks to align UCT's core mission with sustainable development through ensuring facilities, research and teaching are linked to create a living laboratory for sustainability (UCT, 2019b). The curriculum is adapted and reformed as knowledge evolves to embed sustainability consciousness with establishing the master's program on climate change and sustainable development. This program trains the students in addressing urgent social and environmental issues that plague the entire society by undertaking innovation initiatives. Students are also incorporated in curriculum development through promoting "afropolitanism", which guarantees students voices are represented in the curriculum development and teaching environments (UCT, 2018c). Sustainable teaching is also promoted through UCTs venture towards culturing social responsiveness in its graduates and this move has seen several student bodies on outreach agendas. For instance, the Green Campus Initiative (GCI) extends outreach on the message of sustainability and assists in the opening of eco clubs in schools and the community. The Township Debating League and the Students Health and Welfare Centres Organisation (SHAWCO) foster responsible citizenship in South Africa through health, education and social initiatives. The Engineers Without Borders outreach arm facilitates the activation, generation, and usage by transferring engineering knowledge that is useful to society at large (UCT, 2019b). Sustainable teaching efforts at UCT are also recognised through lecturer development efforts necessary to equip lecturers with new teaching strategies and methodologies to improve 
their quality of instruction. Lecturer development takes place in different forms at this world-class institution, such as training and distinguished teacher awards that motivate lecturers to engage in active and transformative sustainable teaching. To achieve all this, lecturers should be up to date in their knowledge and teaching methodologies. The emphasis on ensuring sustainable teaching and lecturer development is crucial as teaching and learning are core functions of the university and, as such responsible for ensuring a stable workforce with attractive attributes towards critical thinking, technical and literary competence that can impact the future. UCT, as an incentive, has an active distinguished teacher award system that recognises teaching staff within the university and places a high emphasis on recognition of excellent teaching. The award seeks to recognise the efforts of teachers who place importance on ensuring sustainable teaching that is learner-centred and invigorates critical thinking. Lecturers are awarded for instilling a teaching philosophy through a dynamic and transformative pedagogical approach to learning and their contribution to a curriculum for the future that features transformation and innovation. In 2017, for example, several lecturers were awarded for standing out in their teaching ethics; their statements and attitudes towards teaching indicate their commitments towards sustainable teaching efforts that are crucial for the modern learner (UCT, 2018d). These lecturers' sentiments echo (Kanuka, 2010), who avers that sustainable teaching promotes active learning that ensures proactive engagement between the learner and the lecturer.

"Teaching is what you do when your student says for the 3rd time, 'But I still do not understand!'-physics Lecturer Gregor Leigh (UCT, 2018d).

"My efforts to teach and train came from a desire to improve orthopaedic and, more specifically, spinal surgical care in the region," Professor Dunn of Orthopaedic Surgery (UCT, 2018d).

"For me, teaching is about inspiring others to discover their purpose and potential. Medicine is about compassion, service, altruism and trustworthiness." Professor Prapdeep of General Surgery (UCT, 2018d).

"If you want a law that creates ground-breaking arguments and changes the status quo, you have to be creative in teaching," Associate professor Jacqueline Yeats (UCT, 2018d).

The RISE program in AUC promotes sustainable teaching through learning programs that reinforce environmental issues crucial for Egypt, the Middle East and the North African region. The education programs provided by the RISE program ensure the communication of research findings through learner-friendly programs. The RISE program has concrete modernised plans that will inculcate on-campus education and curriculum programs that emphasise hands-on practical learning processes; this initiative is in tandem with the research by Kanuka (2010) who argues for sustainable teaching is characterised by active and transformative learning. Sustainable teaching and learning at AUC is evidenced by the Living Learning lab, an institution-based learning program that involves students from various disciplines in various research projects. The living-learning lab involves a practical on-campus experience that provides students with hands-on experience making the learning process dynamic and learner-centred. Past living learning labs have satisfactorily ensured various projects such as the green roof experiment that tested sustainable solutions for roof spaces in the institution and the campus, water quality monitoring project that tests the standards and quality of water. Social responsiveness efforts at AUC are evidenced through teaching beyond the campus via public lectures, discussions and various school programs. The AUCs efforts towards ensuring sustainable teaching is identified through the Centre for Sustainability Development (CSD) that supports the development of larger Egypt. The CSD is tasked with developing academic programs in the sustainable development area, ensuring sustainable teaching in these efforts in partnership with national and international institutions. The most tangible of sustainable teaching efforts is evidenced by the presence of the graduate program in sustainable development, whose efforts are to educate innovative and future leaders with a critical understanding of the modern world's challenges. In addition, the AUC provides international university partnerships that provide opportunities for students to have an abroad experience to promote sustainable teaching. Through various academic programs that offer collaborative educational programs, the joint program in political science with Tubigen University and the dual degree in sustainable development with the Politecnico di Milano in Italy (AUC, 2018e, AUC, 2018b).

Comparatively, both world-class institutions engage in substantial efforts towards sustainable teaching by creating living-learning labs that promote practical hands-on experience towards sustainability initiatives. For both institutions, the findings show that sustainability in teaching is promoted on campus and extends their teaching prerogative through social responsiveness via various outreach initiatives that promote sustainability in society. For the UCT, the understanding of sustainable teaching and implementation stretches to the lecturers and has incentives and awards that motivate their lecturers towards sustainable pedagogical methods. In like fashion, both institutions have in place sustainability embedded curriculums and targeted sustainability degree programs 
with significant collaborative academic programs that foster exchange and interactive learning processes.

\subsection{Sustainability in Technology and Innovation}

Sustainable technology and innovation refer to the production and invention of dynamic and innovative technology that is fundamentally crucial to stay at par in the modern world today. Extensive technological advancements characterise WCUs in terms of research laboratories and other infrastructure. They also ensure the best infrastructure in terms of technologically advanced research equipment, up to date and state of the art libraries and laboratories that provide avenues for exploring technology and innovation that is sustainable.

Sustainable technology and innovation initiatives at UCT are evidenced by the iThemba LABS, a technology and innovation research facility funded by the Department of Science and Technology at UCT through collaboration with the National Research Foundation and employs senior scientists offering world-class administrative and infrastructure support. This initiative has, in turn, seen excellent outcomes through the significant growth of the physics community in South Africa, with more publications in the subfields of nuclear, particle and field physics. In addition, the collaboration has significantly accelerated and produced sustainable technology and innovation that has provided avenues for the scientific training of future scientists. The partnership has also accelerated sustainable technological advancement through practical and social innovation while providing modern, up to date scientific training for new generations of scientists and innovators. (AUC, 2018a). Notable sustainable innovation strides at the UCT are also facilitated by the recent improvement of the Airbus A320 aircraft design (UCT, 2018a) and the new invention of Africa's two-legged robot designed by the electrical department engineering. These innovations will provide platforms for biomechanics to better comprehend movement in both humans and animals (UCT, 2019a).

The Green Innovation and Entrepreneurship Program (GIEP) in AUC aids in nurturing innovators and entrepreneurs who are fully equipped with relevant skills, essentially developing sustainable business models that support sustainable development for both the institution and the greater Egypt (AUC, 2018c). The program, a European Union (EU) funded TEMPUS program, brings together through the collaboration of European and Egyptian universities under a joint graduate innovative program. Furthermore, AUC actively supports the transfer of sustainable innovation through ensuring technology licensing and collaborative partnerships to aid the delivery of tangible benefits. This support is further evidenced by the presence of the Technology Transfer Office (TTO) that ensures commercial investment and the licensing of innovations and technology of research by AUC in all research that cuts across several disciplines. In addition, the TTO is tasked to ensure that researchers and inventors are thoroughly motivated and fully satisfied to ensure innovative productions through sustainable research and practice (AUC, 2018f).

As WCUs are technologically smart and resourceful institutions (Lee, 2013), and as such, are capable of fostering sustainable, innovative initiatives in various sectors. Both institutions show tangible and sustainable innovative strides in various sectors through programs and collaborations that foster innovation.

\section{Conclusion}

Sustainability in higher education has achieved much attention; equally, this study aimed to analyse the critical roles played by world-class universities in Africa in fostering sustainability by understanding their sustainability organisation and the varied sustainability initiatives in research, teaching, technology, and innovation.

This study finds that sustainability organisation at both WCUs is rigorous and have an all-comprehensive organisation that is tangible with detailed sustainability approaches. These institutions adopt their sustainability commitments from international organisations such as Talloires and the United Nations sustainability agreements and declarations. While the efforts of these WCUs is mainly on promoting campus/university sustainability, the American University in Cairo further promotes sustainability at the community level through responsive social initiatives. Sustainability organisation at both institutions is also characterised by a less hierarchical approach(bottom-up) that ensures management and leadership of sustainability initiatives is spearheaded by both students and lecturers at individual or departmental levels. The findings also confirm that WCUs in Africa are engaging in sustainable research endeavours that pay attention to environmental sustainability research only but stretch to other vital areas such as food and medicine, as evidenced by the University of Cape Town. Noticeably too, both WCUs have active research collaborations and partnerships to boost sustainable research. Our findings reveal that sustainability in teaching is fostered at both WCUs through practical living-learning labs that provide hands-on experience to learners. Sustainable teaching is also evidenced through redesigning of curriculums to sustainability-embedded curriculums and the improvement of pedagogy methods. Of worth noting is the lecturer development and support at the University of Cape Town, accorded through training and incentives such as distinguished teacher awards to encourage lecturers to inculcate sustainable pedagogy methods. In addition to 
this, these WCUs indicate substantial, sustainable strides towards innovation and technology in various sectors.

Based on this analysis, these WCUs approaches to their sustainability organisation and the various sustainable initiatives in research, teaching technology, and innovation can deduce essential lessons on the different sustainability initiatives and practices. Notwithstanding, these WCUs can have transformative values for other upcoming world-class institutions in Africa. For instance, as both UCT and AUC have comprehensive and detailed sustainability organisation, potential WCUs can improve their sustainability understanding and, therefore, put together comprehensive and detailed sustainability organisations. In addition, the notable strides in fostering sustainability in their research, teaching, technology and innovation can inspire potential WCUs to invest in fostering sustainable initiatives in these areas. An incorporation of missions and goals that address how the university approaches sustainability at the institution/departmental level at universities as suggested by Tziganuk and Gliedt (2017) is a critical starting point for WCUs in Africa towards participating in the sustainability agenda.

As world-class institutions in Africa, these institutions bear profound responsibility in fostering sustainability in their overall activities, in which they are still developing ways of improving their sustainability agendas. Overall, understanding the roles WCUs play in fostering sustainability aids in understanding the higher education for sustainable development (HESD) in African countries. These comparisons illuminate the roles WCUs in Africa play in fostering sustainability practices and initiatives and provide an in-depth understanding and grasp of how world-class institutions can reform and strategise sustainability initiatives and practices by learning from experiences of these WCUs in different and dynamic institutional contexts.

\section{Acknowledgement}

All authors contributed equally to this work.

\section{References}

Association for Advancing Sustainability in Higher Education (AASHE). (2019). STARS -Technical Manual. Retrieved from https://stars.aashe.org/pages/about/technical-manual.html

Association of African Universities (AAU). (2009). Abuja Declaration on Sustainable Development in Africa: The Role of Higher Education. Retrieved from Retrieved from https://www.ancefa.org/IMG/pdf/Abuja_Declaration_Rev_20Aug.pdf

Aleixo, A. M., Leal, S., \& Azeiteiro, U. M. (2018). Conceptualization of sustainable higher education institutions, roles, barriers, and challenges for sustainability: an exploratory study in Portugal. Journal of Cleaner Production, 172, 1664-1673. https://doi.org/10.1016/j.jclepro.2016.11.010

ARUA. (2018). African Research Universities Alliance. Retrieved from http://arua.org.za/about/

American University in Cairo (AUC). (2018a). 10-years-of-south-african-collaboration-with-cern. Retrieved from https://www.news.uct.ac.za/news/research-office/-article/2018-11-28-10-years-of-south-african-collab oration-with-cern

American University in Cairo (AUC). (2018b). Center for Sustainable Development Graduate Program. Retrieved from http://schools.aucegypt.edu/Sustainability/CSD/Pages/graduateprogram.aspx

American University in Cairo (AUC). (2018c). Green Innovation and Entrepneurship Program (GIEP). Retrieved from http://schools.aucegypt.edu/Sustainability/CSD/Pages/GIEP.aspx

American University in Cairo (AUC). (2018d.) Research centres. Retrieved from https://new.aucegypt.edu/research/research-centers

American University in Cairo (AUC). (2018e). Research Institute for a Sustainable Environment (RISE). Retrieved from http://schools.aucegypt.edu/Sustainability/Rise/Pages/Research.aspx

American University in Cairo (AUC). (2018f). Technology Transfer Office. Retrieved from https://new.aucegypt.edu/research/technology-transfer

American University in Cairo (AUC). (2018g). University Research Board. Retrieved from https://new.aucegypt.edu/research/university-research-board

Beringer, A., \& Adomßent, M. (2008). Sustainable university research and development: inspecting sustainability in higher education research. Environmental Education Research, 14, 607-623. https://doi.org/10.1080/13504620802464866

Calder, W., \& Clugston, R. (2003). Progress toward sustainability in higher education. Environmental Law 
Reporter News \& Analysis, 33, 10003-10022.

Casarejos, F., Frota, M., \& Gustavson, L. (2017). Higher education institutions: a strategy towards sustainability. International Journal of Sustainability in Higher Education, 18, 995-1017. https://doi.org/10.1108/IJSHE-08-2016-0159

Fiksel, J., Livingston, R., Martin, J., \& Rissing, S. (2013). Sustainability at the Ohio state university: beyond the physical campus. Journal of Environmental Studies and Sciences, 3, 74-82. https://doi.org/10.1007/s13412-012-0104-X

Griffith, A., \& Moore, W. (2020). A Comparative Analysis of Approaches to Integrating Sustainability into the Curriculum at a University in a Small Island Developing State in the Caribbean. In E. Sengupta, P. Blessinger, \& T. S. Yamin (Eds.), Integrating Sustainable Development into the Curriculum (Innovations in Higher Education Teaching and Learning, pp. 41-56), Emerald Publishing Limited, Bingley. https://doi.org/10.1108/S2055-364120200000018021

Gómez, F., Sáez-navarrete, C., LioI, S., \& Marzuca, V. (2015). Adaptable model for assessing sustainability in higher education. Journal of Cleaner Production, 107, 475-485.

https://doi.org/10.1016/j.jclepro.2014.07.047

Harvard. (2019). Green Harvard.

International Association of Universities (IAU). (1991). The Halifax Declaration. Retrieved from https://www.iau-hesd.net/sites/default/files/documents/rfl_727_halifax_2001.pdf [Accessed 5.16 2020].

International Association of Universities (IAU). (1993b). The Swansea Declaration. Retrieved from https://www.iau-hesd.net/sites/default/files/documents/the_swansea_declaration.pdf

International Association of Universities (IAU). (2001). The Lu«neburg Declaration on Higher Education for Sustainable Development. Retrieved from https://www.iau-hesd.net/sites/default/files/documents/luneburgdeclaration_0.pdf

International Association of Universities (IAU). (2002). The Ubuntu Declaration. Retrieved from https://www.icsu.org/publications/other-key-icsu-statements/ubuntu-declaration-on-education-science-and-t echnology-for-sustainable-development/194_DD_FILE_10-3-1_Ubuntu_Declaration.pdf

International Association of Universities (IAU). (2005). Graz Declaration on Committing Universities to Sustainable Development. Retrieved from

https://www.iauhesd.net/sites/default/files/documents/2005_graz_declaration_on_committing_universities_t o_sustainable_development_fr.pdf

International Association of Universities (IAU). (2009a). Torino Declaration on Education and Research for Sustainable and Responsible Development (Turin Declaration). Retrieved from https://www.iauhesd.net/sites/default/files/documents/g8torino_declaration.pdf

International Association of Universities (IAU). (2009b). Bonn Declaration. Retrieved from https://www.iau-hesd.net/sites/default/files/documents/2009_-_bonn_declaration_en.pdf

International Association of Universities (IAU). (1993a). Kyoto Declaration on Sustainable Development. Retrieved from https://www.iau-aiu.net/sites/all/files/Sustainable_Development_Policy_Statement.pdf

International Association of Universities (IAU). (1994). Copernicus Charter. Retrieved from https://www.iau-hesd.net/sites/default/files/documents/copernicus.pdf

ISO. (2014). ISO 26000: 2010 Guidance on Social Responsibility. Geneva: International Organization for Standardization.

IARU. (2018). The International Alliance of Research Universities. Retrieved from http://www.iaruni.org

Kanuka, H. (2010). Characteristics of effective and sustainable teaching development programmes for quality teaching in higher education. Higher Education Management and Policy, 22(2). https://doi.org/10.1787/hemp-22-5kmbq08ncr25

Lauder, A., Sari, R., Suwartha, N., \& Tjahjono, G. (2015). Critical review of a global campus sustainability ranking: GreenMetric. Journal of Cleaner Production, 108, 852-863. https://doi.org/10.1016/j.jclepro.2015.02.080

Leal Filho, W., Raath, S., Lazzarini, B., Vargas, V. R., deSouza, L., .. Orlovic, V. L. (2018). The role of transformation in learning and education for sustainability. Journal of Cleaner Production, 199, $286-295$. 
https://doi.org/10.1016/j.jclepro.2018.07.017

Lee, J. (2013). Creating world-class universities: Implications for developing countries. PROSPECTS, 43, 233-249. https://doi.org/10.1007/s11125-013-9266-x

Lozano, R., Ceulemans, K., Alonso-almeida, M., Huisingh, D., Lozano, F., Waas, T., Lambrechts, W., Lukman, R., \& Hugé, J. (2015). A review of commitment and implementation of sustainable development in higher education: results from a worldwide survey. Journal of Cleaner Production, 108, 1-18. https://doi.org/10.1016/j.jclepro.2014.09.048

Lozano, R., Lukman, R., Lozano, f., Huisingh, D., \& Lambrechts, W. (2013). Declarations for sustainability in higher education: becoming better leaders, through addressing the university system. Journal of Cleaner Production, 48, 10-19. https://doi.org/10.1016/j.jclepro.2011.10.006

Lozano, R., Merrill, M., Sammalisto, K., Ceulemans, K., \& Lozano, F. (2017). Connecting competences and pedagogical approaches for sustainable development in higher education: A literature review and framework proposal. Sustainability, 9, 1889. https://doi.org/10.3390/su9101889

Lozano, R., Barreiro-Gen, M., Lozano, F. J., \& Sammalisto, K. (2019). Teaching sustainability in European higher education institutions: assessing the connections between competences and pedagogical approaches. Sustainability, 11(6), 1602. https://doi.org/10.3390/su11061602

Martin, S., \& Jucker, R. (2005). Educating earth-literate leaders. Journal of Geography in Higher Education, 29, 19-29. https://doi.org/10.1080/03098260500030298

Martínez Casanovas, M., Ruíz-Munzón, N., \& Buil-Fabregá, M. (2021), Higher education: the best practices for fostering competences for sustainable development through the use of active learning methodologies. International Journal of Sustainability in Higher Education. https://doi.org/10.1108/IJSHE-03-2021-0082

Mintz, K., \& Tal, T. (2018), The place of content and pedagogy in shaping sustainability learning outcomes in higher education. Environmental Education Research, 24(2), 207-229. https://doi.org/10.1080/13504622.2016.1204986

U. N. (1987). Report of the World Commision on Environment and Development: Our common Future. New York (NY).

U. N. (1992). Agenda 21. Retrieved from https://sustainabledevelopment.un.org/content/documents/Agenda21.pdf

U. N. (2012). Report of the United Nations Conference on Sustainable Development. New York (NY): United Nations.

Higher Education Sustainability Initiative (HESI). (2021). Retrieved from https://sustainabledevelopment.un.org/sdinaction/hesi

Declaration of the United Nations Conference on the Human Environment. (2021). Retrieved from http://www.un-documents.net/unchedec.htm

Higher Education and Research for Sustainable Development (HESD). (2021). Retrieved from https://sustainabledevelopment.un.org/partnership/?p=11748

Saqib, Z. A., Zhang, Q., Ou, J., Saqib, K. A., Majeed, S., \& Razzaq, A. (2020). Education for sustainable development in Pakistani higher education institutions: an exploratory study of students' and teachers' perceptions. International Journal of Sustainability in Higher Education, 21(6), 1249-1267. https://doi.org/10.1108/IJSHE-01-2020-0036

Sinakou, E., Boeve-de Pauw, J., Goossens, M., \& Van Petegem, P. (2018), Academics in the field of education for sustainable development: their conceptions of sustainable development. Journal of Cleaner Production, 184, 321-332. https://doi.org/10.1016/j.jclepro.2018.02.279

Steffen, W., Richardson, K., Rockström, J., Cornell, S., Fetzer, I., Bennett, E., Biggs, R., Carpenter, S., De vries, W., \& De wit, C. (2015). Planetary boundaries: Guiding human development on a changing planet. SCIENCE, 347, 1259855. https://doi.org/10.1126/science.1259855

Stephens, J., Hernandez, M., Román, M., Graham, A., \& Scholz, R. (2008). Higher education as a change agent for sustainability in different cultures and contexts. International Journal of Sustainability in Higher Education, 9, 317-338. https://doi.org/10.1108/14676370810885916

Tziganuk, A., \& Gliedt, T. (2017), Comparing faculty perceptions of sustainability teaching at two US 
universities. International Journal of Sustainability in Higher Education, 18(7), 1191-1211. https://doi.org/10.1108/IJSHE-01-2016-0006

University of Cape Town (UCT). (2018a). Impacting airbus aircraft design. Retrieved from https://www.news.uct.ac.za/news/research-office/-article/2018-11-28-impacting-airbus-aircraft-design

University of Cape Town (UCT). (2018b). Infectious-diseases-treatment-breakthrough. Retrieved from https://www.news.uct.ac.za/news/research-office/-article/2018-11-15-infectious-diseases-treatment-breakthr ough

University of Cape Town (UCT). (2018c). Teaching and Learning. Retrieved from http://www.uct.ac.za/main/teaching-and-learning

University of Cape Town (UCT). (2018d). Teaching and learning under distinguished teacher award. Retrieved from http://www.uct.ac.za/main/teaching-and-learning/distinguished-teacher-award

University of Cape Town (UCT). (2019a). Meet aleka Africas first two legged robot. Retrieved from https://www.news.uct.ac.za/news/research-office/-article/2019-03-15-meet-baleka-africas-first-two-legged-r obot

University of Cape Town (UCT). (2019b.) Sustainability. Retrieved from http://www.uct.ac.za/main/explore-uct/sustainability

Vargas, V. R., Lawthom, R., Prowse, A., Randles, S., \& Tzoulas, K. (2019), Sustainable development stakeholder networks for organisational change in higher education institutions: a case study from the UK. Journal of Cleaner Production, 208, 470-478. https://doi.org/10.1016/j.jclepro.2018.10.078

Waas, T., Verbruggen, A., \& Wright, T. (2010). University research for sustainable development: definition and characteristics explored. Journal of cleaner production, 18, 629-636. https://doi.org/10.1016/j.jclepro.2009.09.017

Wu, Y., \& Shen, J. (2016). Higher education for sustainable development: a systematic review. International Journal of Sustainability in Higher Education, 17(5), 633-651. https://doi.org/10.1108/IJSHE-01-2015-0004

WUN. (2018). The Worldwide Universities Network. Retrieved from http://www.uct.ac.za/main/research/intl-research-partners/wun/research

Yale. (2019). Sustainability. Retrieved from https://sustainability.yale.edu/vision-approach

Zou, Y., Zhao, W., Mason, R., \& Li, M. (2015). Comparing sustainable universities between the United States and China: Cases of Indiana university and Tsinghua university. Sustainability, 7, 11799-11817. https://doi.org/10.3390/su70911799

\section{Copyrights}

Copyright for this article is retained by the author(s), with first publication rights granted to the journal.

This is an open-access article distributed under the terms and conditions of the Creative Commons Attribution license (http://creativecommons.org/licenses/by/4.0/). 